\title{
PARTISIPASI POLITIK PEMILIH PEMULA DALAM PEMILIHAN \\ UMUM 2019 DI KELURAHAN SUMBER KECAMATAN \\ BANJARSARI KOTA SURAKARTA
}

Artikel

Penulis

\author{
Wisnu Dani Prasetyo ${ }^{1}$ \\ Mahasiswa Program Studi PPKn \\ FKIP Univet Bantara Sukoharjo \\ Toni Harsan ${ }^{2}$ \\ Dosen Program Studi PPKn \\ FKIP Univet Bantara Sukoharjo \\ Pujiyana $^{3}$ \\ Dosen Program Studi PPKn \\ FKIP Univet Bantara Sukoharjo
}

\begin{abstract}
ABSTRAK
Tujuan penelitian ini adalah : 1) Untuk mengetahui Partisipasi politik pemilih pemula dalam pemilihan umum 2019 di Kelurahan Sumber Kecamatan Banjarsari Kota Surakarta., 2) Untuk mengetahui faktor-faktor yang mempengaruhi partisipasi politik pemilih pemula di Kelurahan Sumber Kecamatan Banjarsari Kota Surakarta.,3)Untuk mengetahui bentuk-bentuk partisipasi politik yang mempengaruhi partisipasi politik pemilih pemula di Kelurahan Sumber Kecamatan Banjarsari Kota Surakarta.

Penelitian ini dilakukandi Kelurahan Sumber Kecamatan Banjarsari Kota Surakarta.,. Penelitian dilakukan dalam waktu3 bulan pada bulan mei 2019 zsampai denganJuli 2019. Subjek penelitianini adalahpemilih pemula di lingkungan Kelurahan Sumber yang berjumlah 60 orang terdiri dari 35 orang laki-laki dan 25 orang perempuan.Teknik pengumpulan data menggunakan teknik angket, wawancara,dokumentasi,dan observasi..

Berdasarkan hasil penelitiandapat disimpulkan: 1) bahwa partisipasi politik pemilih pemula di Kelurahan Sumber dikategorikan tinggi, hal ini karena pemilih pemula sangat antusias dalam memberikan hak suaranya .2)partisipasi politik pemilih pemula di Kelurahan Sumber dipengaruhi beberapa faktor anatara lain pengaruh orang tua, kondisi lingkungan, pengalaman beorganisasi, modernisasi.3)partisipasi politik pemilih pemula di Kelurahan Sumber dipengaruhi bentuk-bentuk partisipasi politik seperti kegiatan pemilihan, kampanye, lobby, kegiatan organisasi, contacting, tindakan kekerasan.
\end{abstract}

Kata-Kata Kunci : Partisipasi Politik Pemilih Pemula dan Pemuli 2019 


\title{
POLITICAL PARTICIPATION OF BEGINNER VOTERS IN GENERAL ELECTION 2019 IN KELURAHAN SUMBER KECAMATAN \\ BANJARSARI KOTA SURAKARTA
}

\author{
Article \\ Author \\ Wisnu Dani Prasetyo \\ PPKn Study Program Students \\ FKIP Univet Bantara Sukoharjo \\ Toni Harsan ${ }^{2}$ \\ Lecturer of PPKn Study Program \\ FKIP Univet Bantara Sukoharjo \\ Pujiyana ${ }^{3}$ \\ Lecturer of PPKn Study Program \\ FKIP Univet Bantara Sukoharjo
}

\begin{abstract}
The purpose of this study are: 1) To find out the political participation of novice voters in the 2019 general election in Sumber Subdistrict, Banjarsari Subdistrict, Surakarta City, 2) To determine the factors that influence the political participation of novice voters in Sumber Subdistrict, Banjarsari Subdistrict, Surakarta City, 3) To find out the forms of political participation that affect the political participation of novice voters in Sumber District, Banjarsari Subdistrict, Surakarta City. This research was conducted in Sumber Village, Banjarsari Subdistrict, Surakarta City. The study was conducted in 3 months in May 2019 until July 2019. The subjects of this study were beginner voters in the Sumber Kelurahan environment, amounting to 60 people consisting of 35 men and 25 women. Data collection techniques using questionnaires, interviews, documentation, and observation .. Based on the results of the study it can be concluded: 1) that the political participation of novice voters in Sumber Village is categorized as high, this is because novice voters are very enthusiastic in giving their voting rights. 2) The political participation of novice voters in Sumber Village is influenced by several factors other than the influence of parents, environmental conditions, experience of organization, modernization. 3) Political participation of novice voters in Sumber Village is influenced by forms of political participation such as election activities, campaigns, lobbying, organizational activities, contacting, acts of violence.
\end{abstract}

\section{Keywords: Political Participation of Beginner Voters and Pemul 2019}




\section{CIVICS EDUCATION AND SOCIAL SCIENSE JOURNAL(CESSJ)}

\section{Pendahuluan}

Dilihat dari tingkat kesadaran para pemilih pemula dalam pemilu, menunjukan perbedaan yang didasarkan pada kurangnya pengalaman dan pemahaman belajar berpolitik, ada pemilih pemula yang menggunakan hak pilih mereka untuk berpartisipasi lewat pesta demokrasi, namun ada juga sebagai pemilih pemula mengambil jalan untuk tidak memilih atau golongan putih karena bagi mereka pribadi, nasib mereka di tanggung mereka sendiri dan bukan pemerintah. Karena dari cara mereka melihat hal ini masih belum terbiasa dikarenakan banyaknya pengaruhpengaruh dari lingkungan sekitar, lewat pergaulan dari teman-teman, ada juga pemilih pemula ini juga melihat cara pendekatan dari para kandidat Calon Presiden dalam hal ini presiden dan wakil presiden, politik uang (money politik) calon presiden. Dipaksa atau dibujuk, dan rasa ingin tahu. Lewat pemilu ini dapat dilihat bagaimana partisipasi politik para pemilih pemula untuk menggunakan hak suara untuk mensukseskan pemilihan umum di Kota Surakarta..

Pendidikan politik bagi warga negara yang menjadi pemilih pemula yang merupakan tanggung jawab bersama. Pendidikan merupakan usaha sadar membimbing anak kearah kesempurnaan baik jasmani maupun rohani. Pendidikan berusaha untuk mengembangkan potensi yang telah ada pada anak dengan memberi bekal sebaik mungkin agar anak tersebut berpikir serta bertanggung jawab terhadap segala aktifitas yang dilakukan sebagai makhluk yang berTuhan dan makhluk sosial.
Partisipasi politik merupakan aspek penting dalam sebuah tatanan negara demokrasi, sekaligus merupakan ciri khas adanya moderniasi politik. Secara konseptual partisipasi politik merupakan kegiatan sesorang atau sekelompok orang untuk ikut serta secara aktif dalam kehidupan politik, dangan jalan memilih pimpinan negara secara langsung mempengaruhi kebijakan pemerintah. Kegiatan ini mencakup pemilihan umum, menghadiri rapat umum, menjadi anggota suatu partai atau kelompok penting, dan lain sebagainya.

A. Rahman (2007: 285) asumsi yang mendasari demokrasi (partisipasi) adalah orang yang paling tahu tentang apa yang baik bagi dirinya adalah orang itu sendiri. Karena keputusan politik yang dibuat dan dilaksanakan oleh pemerintah menyangkut dan mempengaruhi kehidupan warga negara maka warga masyarakat berhak ikut serta mentukan isi keputusan yang mempengaruhi proses pembuatan dan pelaksanakan keputusan politik. Kegiatan warga negara itu meliputi mempengaruhi isi kebijakan umum dan ikut menentukan dan pelaksana keputusan politik.

Bermacam-macam partisipasi politik yang terjadi di berbagai negara dan berbagai waktu. Kegiatan politik konvensional adalah bentuk partisipasi yang normal dalam demokrasi modern. Bentuk non-konvensional seperti petisi, kekerasan dan revolusioner. Bentukbentuk dan frekuensi partisipasi politik dapat dipakai sebagai ukuran untuk stabilitas sistem politik, integritas kehidupan politik dan kepuasan atau ketidakpuasan warga negara.

Dalam hubungan dengan demokrasi, partisipasi politik berpengaruh terhadap legitimasi 


\section{CIVICS EDUCATION AND SOCIAL SCIENSE JOURNAL(CESSJ)}

masyarakat terhadap jalannya suatu pemerintahan. Dalam suatu pemilu misalnya partisipasi politik berpengaruh terhadap legitimasi masyarakat kepada pasangan calon yang terpilih. Setiap masyarakat memiliki preferensi dan kepentingan masing-masing untuk menentukan pilihan mereka dalam pemilu. Bisa dikatakan bahwa masa depan pejabat publik yang terpilih dalam suatu Pemilu tergantung pada preferensi masyarakat sebagai pemilih. Tidak hanya itu, partisipasi politik masyarakat dalam pemilu dapat dipandang sebagai kontrol masyarakat terhadap suatu pemerintahan. Kontrol yang diberikan beragam tergantung dengan tingkat partisipasi politik masing-masing. Selain sebagai inti dari demokrasi, partisipasi politik juga berkaitan erat dengan pemenuhan hakhak politik warga negara. Wujud dari pemenuhan hak-hak politik adalah adanya kebebasan bagi setiap warga untuk menyatakan pendapat dan berkumpul. Seperti yang tertuang dalam UUD 1945 pasal 28E ayat 3: "setiap orang berhak atas kebebasan berserikat mengeluarkan berkumpul dan pendapat".

\section{Kajian Teori}

Partisipasi politik adalah salah satu aspek penting suatu demokrasi. Partisipasi politik merupakan ciri khas dari modernisasi politik. Adanya keputusan politik yang di buat dan dilaksanakan oleh pemerintah menyangkut dan mempengaruhi kehidupan warga negara, maka warga negara berhak ikut serta menentukan isi keputusan politik.
Menurut Miriam Budiardjo (2008: 367) Partisipasi Politik adalah kegiatan seseorang atau kelompok orang untuk ikut serta secara aktif dalam kehidupan politik, antara lain dengan jalan memilih pimpinan negara dan, secara langsung atau tidak langsung, memengaruhi kebijakan pemerintah (public policy). Kegiatan ini mencangkup tindakan seperti memberikan suara dalam pemilihan umum, menghadapi rapat umum, mengadakan hubungan (contacting) atau lobbying dengan pejabat pemerintah atau anggota parlemen, menjadi anggota partai atau salah satu gerakan sosial dengan direct actionnya, dan sebagainya.

Menurut Ramlan Surbakti (1992: 140) menyebutkan dua variabel penting yang mempengaruhi tinggi rendahnya partisipasi politik seseorang. Pertama, aspek kesadaran politik terhadap pemerintah (sistem politik). Yang dimaksud dalam kesadaran politik adalah kesadaran hak dan kewajiban warga negara. Misalnya hak politik, hak ekonomi, hak perlindungan hukum, kewajiban ekonomi, kewajiban sosial dan lain-lain. Kedua, menyangkut bagaimana penilaian serta apresiasi terhadap kebijakan pemerintah dan pelaksanaan pemerintahnya. menurut Hutington dan Nelson yang dikutip oleh Cholisin (2007: 151) adalah kegiatan warga Negara yang bertindak sebagai pribadi-pribadi yang dimaksud untuk mempengaruhi pembuatan keputusan oleh pemerintah.

.Partisipasi politik merupakan suatu aktivitas tentu dipengaruhi oleh beberapa faktor. Menurut Ramlan Surbakti (1992:140) menyebutkan dua variable penting yang mempengaruhi tinggi rendahnya tingkat partisipasi 


\section{CIVICS EDUCATION AND SOCIAL SCIENSE JOURNAL(CESSJ)}

politik seseorang. Pertama, aspek kesadaran politik terhadap pemerintah (sistem politik). Yang dimaksud dalam kesadaran politik adalah kesadaran hak dan kewajiban warga negara. Misalnya hak politik, hak ekonomi, hak perlindungan hukum, kewajiban ekonomi, kewajiban sosial dll. Kedua, menyangkut bagaimana penilaian serta apresiasi terhadap kebijakan pemerintah dan pelaksanaan pemerintahnya. Selain itu ada faktor yang berdiri sendiri (bukan variable independen). Artinya bahwa rendah kedua faktor itu dipengaruhi oleh faktor-faktor lain, seperti status sosial, afiliasi politik orang tua, dan pengalaman beroganisasi. Yang dimaksud status sosial yaitu kedudukan seseorang berdasarkan keturunan, pendidikan, pekerjaan, dan lain-lain. Selanjutnya status ekonomi yaitu kedudukan seseorang dalam lapisan masyarakat, berdasarkan pemilikan kekayaan. Seseorang yang mempunyai status sosial dan ekonomi tinggi diperkirakan tidak hanya mempunyai pengetahuan politik, akan tetapi memiliki minat serta perhatian pada politik dan kepercayaan terhadap pemerintah (Ramlan Surbakti, 2006:144-145).

Selanjutnya menurut Myron Weimer partisipasi politik di pengaruhi oleh beberapa hal, seperti yang dikutip oleh Mohtar Mas'oed dan Collin MacAndrews (2011:56-57), sebagai berikut :

1. Modernisasi Modernisasi disegala bidang akan berimplikasi pada komensialisme pertanian, industrial, meningkatkan arus urbanisasi, peningkatan kemampuan baca tulis, perbaikan pendidikan dan pengembangan media massa atau media komunikasi secara luas.

2. Terjadi perubahan struktur kelas sosial Terjadinya perubahan kelas struktur kelas baru itu sebagai akibat dari terbentuknya kelas menengah dan pekerja baru yang meluas era industralisasi dan modernisasi.

3. Pengaruh kaum intelektual dan meningkatnya komunikasi massa modern Ide-ide baru seperti nasionalisme, liberalisme, membangkitkan tuntuntantuntutan untuk berpartisipasi dalam pengambilan suara.

4. Adanya konflik diantara pemimpin-pemimpin politik Pemimpin politik yang bersaing merebutkan kekuasaan sering kali untuk mencapai kemenangannya dilakukan dengan cara mencari dukungan massa.

5. Keterlibatan pemerintah yang semakin luas dalam unsur ekonomi,sosial dan budaya

Meluasnya ruang lingkup aktivis pemerintah ini seringkali merangsang timbulnya tuntutantuntutan organisasi untuk ikut serta dalam mempengaruhi pembuatan keputusan politik.

Sementara itu menurut Milbrath yang dikutip oleh Michael Rush dan Althof (1989:168) memberikan alasan bervariasi mengenai partisipasi seseorang, yaitu: Berknaan dengan penerimaan perangsang politik. Milbrath menyatakan bahwa keterbukaan dan kepekaan seseorang 


\section{CIVICS EDUCATION AND SOCIAL SCIENSE JOURNAL(CESSJ)}

terhadap perangsang politik melalui kontak-kontak pribadi, organisasi dan melalui media massa akan memberikan pengaruh bagi keikutseertaan seseorang dalam kegiatan politik. Berkenaan dengan karekteristik sosial seseorang. Dapat disebutkan bahwa status ekonomi, karekter suku, usia jenis kelain dan keyakinan (agama). Karakter seseorang berdasarkan faktorfaktor tersebut memiliki pengaruh yang relatif cukup besar terhadap partisipasi politik. Menyingkat sifat dan sistem partai tempat individu itu hidup. Seseorang yang hidup dalam negara yang demokratis, partai-partai politiknya cenderung mencari dukungan massa dan memperjuangkan kepentingan massa, sehingga massa cenderung berpartisipasi dalam politik. Adanya perbedaan regional. Perbedaan ini merupakan aspek lingkungan yang berpengaruh terhadap perbedaaan watak dan tingkah laku individu. Dengan perbedaan regional itu pula yang mendorong perbedaan perilaku politik dan partisipasi politik. Partisipasi pemilih pemula dalam pilbup langsung memang erat kaitanya dengan faktor-faktor yang mempengaruhinya. Banyak pertimbangan dalam menggunakan hak pilihnya. Bisa melihat dari sisi visi misi kandidat yang bagus meskipun tidak ada jaminan setelah kandidat terpilih. Selain itu berupa acuan yang digunakan untuk memilih adalah mereka kandidat yang memberikan uang, dan kandidat yang diusung oleh partai yang dianggap pemilih pemula sesuai dengan kriterianya. Pada perilaku pemilih yang rasional pemilih akan menentukan pilihannya berdasarkan isu politik dan kandidat yang diajukan serta kebijakan yang dinilai menguntungkan baginya yang akan ia peroleh apabila kandidat pilihannya terpilih. Pemilih yang rasional tidak hanya pasif dalam berpartisipasi tetapi aktif serta memiliki kehendak bebas.

Rahman H.I (2007: 288) menyatakan bahwa secara umum tipologi partisipasi sebagai kegiatan dibedakan menjadi: partisipasi aktif, yaitu partisipasi yang berorientasi pada proses input dan output. partisipasi pasif, yaitu partisipasi yang berorientasi hanya pada output, dalam arti hanya menaati peraturan pemerintah, menerima dan melaksanakan saja setiap keputusan pemerintah. golongan putih (golput) atau kelompok apatis, karena menggapsistem politik yang ada menyimpang dari yang dicita-citakan.

Milbrath dan Goel yang dikutip oleh Cholisin (2007: 152) membedakan partisipasi politik menjadi beberapa kategori yakni : Partisipasi politik apatis orang yang tidak berpartisipasi dan menarik diri dari proses politik. Partisipasi politik spector orang yang setidak-tidaknya pernah ikut memilih dalam pemilihan umum. Partisipasi politik gladiator mereka yang secara aktif terlibat dalam proses politik, yakni komunikator, spesialis mengadakan kontak tatap muka, aktivis partai dan pekerja kampanye dan aktivis masyarakat. Partisipasi politik pengritik Orang-orang yang berpartisipasi dalam bentuk yang tidak konvensional.

Dengan demikian dapat dinyatakan bahwa orientasi partisipasi politik aktif terletak pada input dan output politik. Sedangkan partsipasi pasif terletak pada outputnya saja. Selain itu juga ada anggapan masyarakat dari sistem politik yang ada dinilai menyimpang dari apa yang 


\section{CIVICS EDUCATION AND SOCIAL SCIENSE JOURNAL(CESSJ)}

dicita-citakan sehingga lebih menjurus kedalam partisipasi politik yang apatis. Pemberian suara dalam pilbup merupakan salah satu wujud partisipasi dalam politik yang terbiasa. Kegiatan ini walaupun hanya pemberian suara, namun juga menyangkut semboyan yang diberikan dalam kampanye, bekerja dalam membantu pemilihan, membantu tempat pemungutan suara dan lain-lain.

Sedangkan Olsen yang dikutip Oleh A. Rahman H.I (2007: 289) memandang partisipasi sebagai dimensi utama startifikasi sosial.Ia membagi partisipasi menjadi enam lapisan, yaitu pemimpin politik, aktivitas politik, komunikator (orang yang menerima dan menyampaikan ide-ide, sikap dan informasi lainnya kepada orang lain), warga masyarakat, kelompok marginal (orang yang sangat sedikit melakukan kontak dengan sistem politik) dan kelompok yang terisolasin(orang yang jarang melakukan partisipasi politik).

Partisipasi politik juga dapat dikategorikan berdasarkan jumlah pelaku yaitu individual dan kolektif.individual yakni seseorang yang menulis surat berisi tuntutan atau keluhan kepada pemerintah.Sedangkan yang dimaksud partisipasi kolektif ialah kegiatan warganegara secara serentak untuk mempengaruhi penguasa seperti kegiatan dalam proses pemilihan umum.

Partisipasi kolektif dibedakan menjadi dua yakni partisipasi kolektif yang konvensional yang seperti melakukan kegiatan dalam proses pemilihan umum dan partisipasi politik kolektif nonkonvensional (agresif) seperti pemogokan yang tidak sah,melakukan hura-hura, menguasai bangunan umum. Partisipasi politik kolektif agresif dapat dibedakan

menjadi dua yaitu aksi agresif yang kuat dan aksi agresif yang lemah. Suatu aksi agresif dikatakan kuat dilihat dari tiga ukuran yaitu bersifat anti rezim (melanggar peraturan mengenai aturan partisipasi politik normal), mengganggu fungsi pemerintahan dan harus merupakan kegiatan kelompok yang dilakukan oleh monoelit. Sedangkan, partisipasi politik kolektif agresif yang lemah adalah yang tidak memenuhi ketiga syarat tersebut diatas.

Di negara-negara berkembang partisipasi politik cenderung digerakan secara meluas dan diarahkan untuk kepentingan pembangunan. Orangorang yang melakukan demonstrasi atau memberikan suara dengan jalan tersebut tampaknya merupakan wujud nyata dari partisipasi politik yang mudah serta mengundang perhatian dari berbagai kalangan.

Paige dalam Cholisin (2007:153) merujuk pada tinggi rendahnya kesadaran politik dan kepercayaan pemerintah (sistem politik menjadi empat tipe yaitu partisipasi aktif, partisipasi pasif tertekan (apatis), partisipasi militan radikal, dan partisipasi pasif.

Partisipasi aktif, yaitu apabila seseorang memiliki kesadaran politik dan kepercayaan kepada pemerintah tinggi. Sebaliknya jika kesadaran politik dan kepercayaan kepada pemerintah rendah maka partisipasi politiknya cenderung pasif-tertekan (apatis). Partisipasi militan radikal terjadi apabila kesadaran politik tinggi tetapi kepercayaan kepada pemerintah sangat rendah. Dan apabila kesadaran politik sangat rendah tetapi kepercayaan terhadap pemerintah sangat tinggi maka partisipasi ini disebut tidak aktif (pasif). 


\section{CIVICS EDUCATION AND SOCIAL SCIENSE JOURNAL(CESSJ)}

Berbagai bentuk-bentuk partisipasi politik yang terjadi di berbagai Negara dapat dibedakan dalam kegiatan politik yang berbentuk konvensional dan nonkonvensional termasuk yang mungkin legal (petisi) maupun ilegal (cara kekerasan atau revolusi). Bentukbentuk dan frekuensi partisipasi politik dapat dipakai sebagai ukuran untuk menilai stabilitas sistem politik, integritas kehidupan politik, kepuasan atau ketidak puasan warga negara.

Bentuk-bentuk partisipasi politik yang dikemukakan oleh Almond yang dikutip oleh Mohtar Mas'oed (2011:57-58) yang terbagai dalam dua bentuk yaitu partisipasi politik konvensional dan partisipasi politik non konvensional. Adapun rincian bentuk partisipasi politik konvensional dan non konvensional: 1. Partisipasi politik konvensional mencakup: a) Pemberian suara atau voting , b) Diskusi politik , c) Kegiatan kampanye
, d) Membentuk dan bergabung dalam kelompok kepentingan e) Komunikasi individual dengan pejabat politik atau administratif 2. Partisipasi politik nonkonvensional mencakup: a) Pengajuan petisi , b) Berdemonstrasi , c) Konfrontasi , d) Mogok, e)Tindak kekerasan politik terhadap harta benda : pengrusakan, pemboman, pembakaran dan f) Tindakan kekerasan politik terhadap manusia: penculikan, pembunuhan, perang gerilya, revolusi.

Kemudian David F. Roft dan Frank yang dikutip oleh A Rahman H.I (2007: 286) bentuk partisipasi warga Negara berdasarkan intensitasnya. Intensitas terendah adalah sebagai pengamat, intensitas menengah yaitu sebagai partisipan, dan intensitas tertinggi sebagai partisipan. Apabila intensitas kegiatan masyarakat dalam kegiatan politik dijenjangkan maka akan membentuk piramida partisipasi politik.

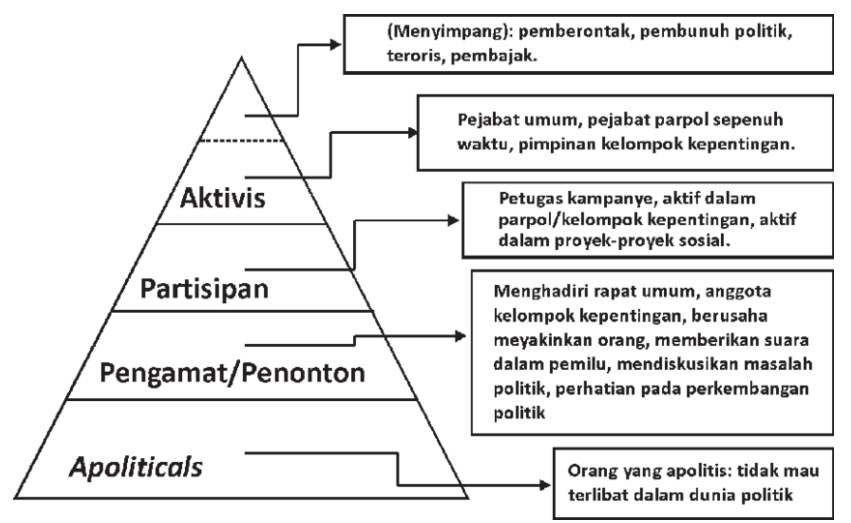

Gambar 1: Piramida partsipasi politik Sumber : Sumarno-2009

Kelompok paling bahwah pada gambar piramida partisipasi politik yaitu kelompok yang sama sekali tidak terlibat dan tidak melakukan kegiatan politik. Oleh Roth dan Wilson ( A Rahman H.I, 2007:287) disebut sebagai kelompok apolitis. Kelompok yang berada di atas apolitis yaitu kelompok pengamat, kelompok ini biasanya menghadiri rapat umum parpol, membicarakan politik, mengikuti perkembanagan lewat media, 


\section{CIVICS EDUCATION AND SOCIAL SCIENSE JOURNAL(CESSJ)}

memberikan suara dalam pemilu. Kemudian satu tingkat di atas kelompok pengamat yaitu kelompok partisipan. Pada kelompok ini aktivitas yang sering dilakukan seperti menjadi petugas kampanye, anggota aktif partai, dan kelompok kepentingan dalam proyek sosial. Kemudian kelompok yang paling atas di tingkat piramida adalah kelompok aktivis. Warga yang tergabung dalam kelompok ini tergolong sedikit jumlahnya, mereka merupakan pejabat partai sepenuh waktu, pemimpin partai atau pemimpin kepentingan.

Adapun bentuk partisipasi yang dilakukan oleh pemuda yakni berupa demonstrasi, pemogokan dan kegiatan protes. Cara yang biasanya dilakukan oleh pemilih pemula untuk turut dalam partisipasi pilbup yaitu bergabung dengan salah satu parpol didaerahnya mengikuti kegiatan kampanye, serta menghadiri diskusi politik didaerahnya.

Ciri utama yang dimiliki pemilih pemula yaitu latar belakang tingkat partisipasi pemilih adalah pendidikan dan jenis kelamin. Setiap komunitas masyarakat memiliki latar belakang yang berbeda-beda. Hal tersebut akan mempunyai pengaruh terhadap tingkat partisipasi politik dalam Pilbup. Serta menjadi bagian partisipasi dalam dinamika kegiatan politik.

Menurut Pahmi Sy. (2010: 54) pemilih adalah warga negara Indonesia yang telah genap berusia17 tahun atau lebih atau sudah/pernah kawin. Pemilih pemula terdiri dari dua kata, yakni pemilih dan pemula. Pemilih adalah orang yang memilih. Sedangkan pemula adalah orang yang mulai atau mula-mula melakukan (KBBI online). Pemilih pemula merupakan pemilih yang berusia antara 17-21 tahun atau baru pertama kali ikut dalam pemilu. Menurut pasal 198 ayat 1 UU No.7 Tahun 2017 menerangkan bahwa pemilih yang mempunyai hak memilih adalah warga Negara Indonesia yang didaftar oleh penyelenggara pemilu dalam daftar pemilih dan pada hari pemungutan suara pemilih genap berumur 17 (tujuh belas) tahun atau lebih atau sudah/pernah kawin. Pengetahuan mereka dengan pemilih lainnya tidak jauh berbeda hanya saja antusiasme dan preferensi.

Pemilih pemula secara umum mereka para pelajar, mahasiswa serta pekerja yang berusia muda. Dalam pesta demokrasi pemilih pemula selama ini menjadi sebuah objek kegiatan politik. Yaitu mereka yang memerlukan bimbingan kearah pertumbuhan potensi dan kemampuan tingkat yang optimal agar dapat berperan baik dalam bidang kegiatan politik. Perlu adanya pendidikan politik agar pemilih pemula berkembang menjadi warga Negara yang baik, yang menghayati nilai-nilai dari bangsanya dan sadar akan kewajiban dalam karangka nilai-nilai yang membingkainya.

Menurut Pahmy Sy. (2010: 54) Ciri-ciri pemilih pemula sebagai berikut : Warga Negara Indonesia dari pemungutan suara sudah berusia 17 tahun atau lebih atau sudah/pernah kawin. Baru mengikuti pemilu, memberikan hak pilihannya pertama kali sejak pemilu yang diselenggarakan di Indonesia dengan rentang usia 17-21 tahun. Mempunyai hak memilih dalam penyelenggaraan pemilu 2019.

Menurut Sekertariat Jendral KPU (2010) pentingnya peran pemilih pemula karena $20 \%$ mereka merupakan bagian dari pemilih. Dengan demikian jumlah pemilih pemula sangatlah besar, 


\section{CIVICS EDUCATION AND SOCIAL SCIENSE JOURNAL(CESSJ)}

dan diharapkan dapat menggunakan hak pilihnya dengan baik. Jangan sampai tidak terdaftar dalam DPT atau kesalahan dalam menggunakan hak pilihnya. Lahirnya dari kelompok ini secara langsung akan memunculkan dampak pencitraan. Untuk pengamanan proses regenerasi kader politik kedepan, walaupun memerlukan biaya yang tidak sedikit. Namun apabila tidak mendapatkan dukungan dari kelompok ini, maka cukup merugikan bagi para parpol atau kandidat yang ingin mendulang tinggi hasil dukungan.

Pemilih pemula kerap menampilkan sisi yang unik, sering kali memunculkan kejutan dan akan menjanjikan secara kuantitas. Pemilih pemula dengan antusiasme tinggi akan relatif rasional haus akan perubahan yang positif. Bagi pemilih pemula yang masih sekolah adapun sosialisasi politik didapatkan melalui mata pelajaran PPKn. PPKn sebagai pendidikan politik terutama dilakukan lewat sekolah merupakan bagian dari sosialisasi politik.

Posisi pemilih merupakan posisi yang sangat penting dalam menentukan arah demokrasi sebuah negara. Menurut Eep Saefullah, untuk menjadikan pemilih betul-betul sebagai penentu, diperlukan setidaknya dua syarat, yaitu: Pemilih memiliki pengetahuan minimal serta menggunakan akal sehat dan nuraninya dan Pemilu yang demokratis, sebab semakin pemilu tersebut tidak demokratis maka para pemilihnya semakin tidak menentukan.

Ada dua pilihan bagi seorang pemilih. Pilihan pertama adalah menjadi pemilih yang bertanggungjawab, yaitu memilih menggunakan akal sehat dan hati nurani serta dengan penuh kesadaran membangun

hubungan

pertanggungjawaban, semacam kontrak dengan orang-orang yang mereka pilih. Setelah pemilu usai, pemilih menjadi penagih janji yang proaktif yang terus terjaga meminta pertanggungjawaban dari orang-orang yang mereka pilih. Sedangkan yang kedua adalah menjadi pemilih yang tidak bertanggungjawab atau tidak memilih sama sekali.

Berdasarkan tipologi Almond dan Verba (1990:16) orientasi politik pemilih pemula ini dikategorikan menjadi : 1) Orientasi kognitif, yaitu pengetahuan dan kepercayaan tentang kandidat, 2) Orientasi politik afektif, yaitu perasaan terhadap pemilu, pengaruh teman terhadap penentuan pilihan, 3) Orientasi politik evaluatif, yaitu keputusan dan pendapat pemilih pemula terhadap parpol/kandidat pilihannya.

Orientasi politik pemilih pemula ini selalu dinamis dan akan berubah mengikuti kondisi dan faktorfaktor yang mempengaruhinya. Orientasi politik sebenarnya merupakan cara pandang suatu golongan masyarakat dalam suatu struktur masyarakat. Timbulnya orientasi itu dilatarbelakangi oleh nilainilai yang ada dalam masyarakat maupun dari luar masyarakat yang kemudian membentuk sikap dan menjadi pola mereka untuk memandang suatu objek politik. Orientasi politik itulah yang kemudian membentuk tatanan dimana interaksiinteraksi yang muncul tersebut akhirnya mempengaruhi perilaku politik yang dilakukan oleh seseorang. Orientasi politik tersebut dapat dipengaruhi oleh orientasi individu dalam memandang objek-objek politik.

Objek orientasi politik meliputi keterlibatan seseorang terhadap : 


\section{CIVICS EDUCATION AND SOCIAL SCIENSE JOURNAL(CESSJ)}

sistem yaitu sebagai suatu keseluruhan dan termasuk berbagai perasaan tertentu seperti patriotisme dan alienasi, kognisi, dan evaluasi suatu bangsa, (2) pribadi sebagai aktor politik, isi dan kualitas, norma-norma kewajiban politik seseorang. Orientasi politik yang dimiliki seseorang akan mendorong terjadinya partisipasi politik.

Karakteristik pemilih pemula mempunyai perbedaan dengan pemilih yang sudah terlibat pemilu periode sebelumnya, yaitu : 1) belum pernah memilih atau melakukan penentuan suara di dalam TPS, 2) belum memiliki pengalaman memilih, memiliki antusias yang tinggi, 4) kurang rasional, 5) pemilih pemula yang masih penuh gejolak dan semangat, yang apabila tidak dikendalikan akan memiliki efek terhadap konflik-konflik sosial di dalam pemilu, 6) menjadi sasaran peserta pemilu karena jumlahnya yang cukup besar, 7) memiliki rasa ingin tahu, mencoba, dan berpartisipasi dalam pemilu, meskipun kadang dengan berbagai latar belakang yang berbeda.

Empat alasan mendasar yang menyebabkan pemilih pemula mempunyai kedudukan dan makna strategis dalam Pemilihan Umum sebagai berikut : 1) alasan kualitatif yaitu bahwa pemilih pemula merupakan kelompok yang mempunyai jumlah secara kuantitatif relatif banyak dari setiap pemilihan umum, Pemilih pemula adalah merupakan satu segmen pemilih yang mempunyai pola perilaku sendiri dan sulit untuk diatur atau diprediksi, 3) kekhawatiran bahwa pemilih pemula akan lebih condong menjadi golput dikarenkan kebingungan karena banyaknya pilihan partai politik yang akhirnya menjadikan mereka tidak memilih sama sekali, 4) masing-masing organisasi sosial politik mengklaim sebagai organisasi yang sangat cocok menjadi penyalur aspirasi bagi pemilih pemula yang akhirnya muncul strategi dari setiap partai politik untuk mempengaruhi pemilih pemula.

Menurut UU No.7 Tahun 2017

tentang Pemilihan Umum. Pemilu adalah sarana kedaulatan rakyat untuk memilih anggota Dewan Perwakilan Rakyat, anggota Dewan Perwakilan Daerah, Presiden dan Wakil Presiden, dan untuk memilih anggota Dewan Perwakilan Rakyat Daerah, yang dilaksanakan secara langsung, umum, bebas, rahasia, jujur, dan adil dalam Negara KesatuanRepublik Indonesia berdasarkan Pancasila dan UndangUndang Dasar Negara Republik Indonesia Tahun 1945. Menurut Morissan (2005:17) pemilihan umum adalah cara untuk mengetahui keinginan rakyat mengenai arah dan kebijakan negara kedepan. Ada 3 macam tujuan pemilu yaitu memungkinkan peralihan pemerintahan secara aman dan tertib untuk melaksanakan kedaulatan rakyat dalam rangka melaksanakan hak asasi warga negara. Ramlan (1992) pemilihan Umum di artikan sebagai mekanisme penyeleksian dan pendelegasian tau penyerahan kedaulatan kepada orang atau partai yang di percayai.

Sebagai sebuah aktivitas politik, pemilihan umum pastinya memiliki fungsi-fungsi yang saling berkaitan atau interdependensi. Adapun fungsifungsi dari pemilihan umum itu sendiri adalah:
1. Sebagai Sarana Legitimasi Politik




\section{CIVICS EDUCATION AND SOCIAL SCIENSE JOURNAL(CESSJ)}

"Fungsi legitimasi ini terutama menjadi kebutuhan pemerintah dan sistem politik. Melalui pemilihan umum, keabsahan pemerintahan yang berkuasa dapat ditegakkan, begitu pula program dan kebijakan yang dihasilkannya. Dengan begitu, pemerintah berdasarkan hukum yang disepakati bersama tak hanya memiliki otoritas untuk berkuasa, melainkan juga memberikan sanksi berupa hukuman dan ganjaran bagi siapapun yang melanggarnya. Menurut Ginsberg" "fungsi legitimasi politik ini merupakan konsekuensi logis dari pemilihan umum. Paling tidak ada tiga alasan kenapa pemilihan umum dapat menjadi suatu legitimasi politik bagi pemerintahan yang berkuasa. Pertama, melalui pemilihan umum, pemerintah sebenarnya bisa meyakinkan atau setidaknya memperbaharui kesepakatan-kesepakatan politik dengan rakyat. Kedua, melalui pemilihan umum pemerintahan dapat pula mempengaruhi perilaku rakyat atau warga negara. Dan ketiga , dalam dunia modern para penguasa dituntut untuk mengadakan kesepakatan dari rakyat ketimbang pemaksaan (coercion) untuk mempertahankan legitimasinya. Gramsci (1971) menunjukkan bahwa kesepakatan (Consent) yang diperoleh melalui hegemoni oleh penguasa ternyata lebih efektif dan bertahan lama sebagai sarana kontrol dan pelestarian legitimasi dari otoritasnya ketimbang penggunaan kekerasan dan dominasi.

2. Fungsi Perwakilan Politik.

"Fungsi ini terutama menjadi kebutuhan rakyat, baik untuk mengevaluasi maupun mengontrol perilaku pemerintahan dan program serta kebijakan yang dihasilkannya. Pemilihan umum dalam kaitan ini

merupakan mekanisme demokratis bagi rakyat untuk menentukan wakilwakil yang dapat dipercaya yang akan duduk dalam pemerintahan.

3. Pemilihan Umum Sebagai Mekanisme Bagi Pergantian atau Sirkulasi Elit Penguasa.

"Keterkaitan pemilihan umum dengan sirkulasi elit didasarkan pada asumsi bahwa elit berasal dari dan bertugas mewakili masyarakat luas atau rakyat. Secara teoritis, hubungan pemilihan umum dengan sirkulasi elit dapat dijelaskan dengan melihat proses mobilitas kaum elit atau non elit yang menggunakan jalur" "institusi politik, dan organisasi kemasyarakatan untuk menjadi anggota elit tingkat nasional, yakni sebagai anggota kabinet dan jabatan yang setara. Dalam kaitan itu, pemilihan umum merupakan saran dan jalur langsung untuk mencapai posisi elit penguasa. Dengan begitu maka melalui pemilihan umum diharapkan bisa berlangsung pergantian atau sirkulasi elit penguasa secara kompetitif dan demokratis. Soerjono Soekanto. Op .cit. hlm 68 Pendidikan Kewarganegaraan (Civic Education): Demokrasi, Hak Asasi Manusia dan Masyarakat Madanai, Edisi Revisi (Cetakan kedua). Jakarta: ICCE UIN Jakarta hlm $96 \quad 13$ d). "Sebagai Sarana Pendidikan Politik Bagi Rakyat Pemilihan umum merupakan salah satu bentuk pendidikan politik bagi rakyat yang bersifat langsung, terbuka dan massal, yang diharapkan bisa mencerdaskan pemahaman politik dan meningkatkan kesadaran masyarakat tentang demokrasi"

Dasar hukum asas-asas pemilu terdapat di dalam UU No.7 Tahun 2017 tentang Pemilihan Umum memiliki yang harus dipatuhi oleh seluruh warga 


\section{CIVICS EDUCATION AND SOCIAL SCIENSE JOURNAL(CESSJ)}

negara tanpa terkecuali demi terciptanya pemilu yang aman dan kondusif tanpa terjadi adanya pertikaian, permusuhan dan kesalahpahaman: Asas Langsung "Yaitu rakyat dapat memilih langsung calon pemimpin yang sesuai dengan pikiran dan hati tanpa bisa diwakili siapapun. Bagi seseorang yang menderita saakit dapat langsung memberikan suaranya dikediamannya dengan pengawasan dari pihk panitia agar kertas yang telah menjadi hak pilihnya tidak diselewengkan atau dibuat curang". Asas Umum "Yaitu pemilihan umum berlaku bagi siap saja tidak memandang jenis kelamin, pekerjaan dan status sosial seseorang, pemilu adalah hak setiap warga negara yang telah memenuhi syarat misalnya telah berusia 17 tahun atu telah menikah serta sehat jasmani rohani (tidak gila)" Asas Bebas "Pemilu berlaku untuk segenap warga negar indonesia yang tinggal dikawasan Negara Kesatuan Republik Indonesia atau yang sedang tinggal diluar negeri. pemilu dapat dilakukaan di negaralain yang sebelumnya telah melewati beberapa prosedur ijin yang resmi dari pihak pemerintaha negaar itu sendiri dan duta besar. setiap pemilih dapat dapat berhak mengubah calon pemimpin yang akan dipilihnya tanpa ancaman atau paksaan orang lain" Asas Rahasia "Memilih calon pemimpin tidak bisa diberitahukan pada orang lain bahkan padaa pihk panitia sekalipun agar tercipta suasana ynag tetap aman , tidak memicu keributan dan saling menghina hanya karena berbeda pilihan. pihak panitai pemilu juga tidak diperbolehkan untuk memberitahukan pilihan orang lain, pilihan diri sendiri, bahkan dilarang bertanya pada pemilih tentang calon pemimpin yang mana yang akan dipilihnya. Asas yang meningkatkan kuliatas pemilu. Asas Adil "Semua pemilih mendapatkan hak dan perlakuan yang sama termasuk perlindungan dari adanya ancaman dan kecurangan dari pihak pihak tertentu. Para pemilihyang berusia manula tidak diperbolehkan ditinggalkan begitu saja tanpa pemberitahuan. Dari beberapa kasus yang pernah terjadi ada beberpa oknum dan orang orang yang tak bertanggung jawab mengendalikan situasitertentu yaitu membiarkan para manula terlambat datang dalam pemilu yang akhirnya mereka kehilangan hak pilihnya karena alasan waktu pemilu telah habis. perlu diketahui bahwa pemilu memiliki waktu yang telah ditentukan oleh panitia penyelenggara batas waktu akhir memilih. hal ini untuk mempermudah penghitungan suara secara serentak disemua provinsi di indonesia dan yang ada diluar negeri". Asas Jujur "Pemilu harus diaksanakan dengan jujur dan apa adanya tanpa ada perwakilan dari keluarga, teman atau orangtua atau lewat perantara lainnya. ketika penghitungan suara dilakukan maka pihak panitia penyelenggara pemilu harus menperbolehkan masyarkat ikut menyaksikan acara penghitungan suara tersebut. Intinya adalah Penghitungan suara harus secara transparan, melibatkan masyarakat dan secara langsung".

Manfaat Pemilihan umum meliputi: Pemilu dapat dijadikan sarana terbaik untuk melakukan pergantian pemimpin secara konstitusional. kondusif dan dapat dirasakan kinerja pemimpinnya selama 5 tahun berkuasa. jika rakyat tidak puas, maka bisa menggantikannya dengan sosok yang baru melalui pemilihan umum. Pemilu 


\section{CIVICS EDUCATION AND SOCIAL SCIENSE JOURNAL(CESSJ)}

dapat dijadikan sebagai tempat rakyat untuk mengeluarkan pendapat tentang siapa yang layak dipilih mereka untuk memimpin negara atau sebagai wadah untuk ikut berpartisipasi dalam proses politik Pemilu dapat dijadikan sebagai tempat bagi para pemimpin politik untuk mendapatkan legitimasi dan mendapatkan kepercayaan dari rakyat. Pemilu dapat dijadikan sebagai wadah untuk mweujudkan kedaulatan rakyat yang kuat dan tidak bisa diintimidasi oleh pihak manapun dan memiliki hak penuh untuk memilih calon pemimpin sesuai dengan keinginan tanpa paksaaan, ancaman atau tekanan dari orang lain agar tidak menjadi penyebab terjadinya tindakan penyalahgunaan kewenangan

Pelaksanaan pemilihan umum berdasarkan UU No.7 Tahun 2017 tentang Pemilihan Umum, sebagai berikut : Dalam Pasal 167 ayat dijelaskan bhawa: Pemilu dilaksanakan setiap 5 (lima) tahun sekali. Hari, tanggal, dan waktu pemungutan suara Pemilu ditetapkan dengan keputusan KPU. Pemungutan suara dilaksanakan secara serentak pada hari libur atau hari yang diliburkan secara nasional.

Tahapan Penyelenggaraan

Pemilu meliputi: perencanaan program dan anggaran serta penyusunan peraturan pelaksanaan Penyelenggaraan Pemilu; pemutakhiran data Pemilih dan penyusunan daftar Pemilih; pendaftaran dan verifikasi Peserta Pemilu; penetapan Peserta Pemilu; penetapan jumlah kursi dan penetapan daerah pemilihan; pencalonan Presiden dan Wakil Presiden serta anggota DPR, DPD, DPRD provinsi, dan DPRD kabupaten/kota; masa Kampanye Pemilu; Masa Tenang; pemungutan dan penghitungan suara; penetapan hasil Pemilu; dan pengucapan sumpah janji Presiden dan Wakil Presiden serta anggota DPR, DPD, DPRD provinsi, dan DPRD kabupaten/kota. (5) Pemungutan suara di luar negen dapat dilaksanakan bersamaan atau sebelum pemungutan suara pada hari sebagaimana dimaksud pada ayat (3).

Geys sebagaimana dikutip (Haris, dkk., 2014: 15) menyebutkan bahwa secara umum,pemilu serentak atau lazim juga disebut sebagai pemilu konkuren (concurren elections) adalah pemilu yang diselenggarakan untuk memilih beberapa lembaga demokrasi sekaligus pada satu waktusecara bersamaan. Jenis-jenis pemilihan tersebut mencakup pemilihan eksekutif dan legislatif di beragam tingkat di negara yang bersangkutan, yang terentang dari tingkat nasional, regionalhingga pemilihan di tingkat lokal.

Dalam penggunaan desain pemilu serentak, praktek yang banyak digunakan adalah penggabungan antara pemilihan eksekutif dengan pemilihan legislatif. Desain ini banyak digunakan di negara-negara Amerika Latin. Bukan hanya untuk tingkat nasional, pemilu serentak di beberapa negara juga dilakukan dengan menggabungkan antara pelaksanaan pemilu nasional dengan pemilu regional atau lokal. Di Amerika Serikat misalnya, di beberapa negara bagian, pemilu bukan hanya memilih presiden, anggota kongres dan senat di tingkat pusat, melainkan dalam waktu bersamaan juga menyelenggarakan pemilihan gubernur dan legislator di tingkat negara bagian (Haris, dkk., 2014: 16).Hanan (2016: 1471) mengemukakan bahwa pelaksanaan pemilu serentak belum tentu akan berdampak positif terhadap penguatan sistem presidensial 


\section{CIVICS EDUCATION AND SOCIAL SCIENSE JOURNAL(CESSJ) \\ Volume 1, Nomor 1, Juni 2019}

multipartai. Ada banyak variabel yang harus dikombinasikan, kombinasi sistem pemilu seperti plurality dan Majority Run Off (MRO). Dampaknya bisa berbeda bila dikombinasikan dengan pemilu eksekutif-legislatif serentak.

Temuan umum dalam berbagai riset, terutama dari sistem presidensial multipartai di AmerikaLatin menunjukkan bahwa gabungan sistem pemilu presiden dengan formula plurality dengan pemilu legislatif secara serentak cenderung dapat membantu penyederhanaan sistem kepartaian. Tetapi ini tetap tergantung misalnya kepada berapa jumlah kandidat presiden yang bertarung. Bila kandidat presidennya banyak, maka dampak reduktif dari sistem plurality terhadap system kepartaian legislatif cenderung memudar. Pandangan lain menyebutkan bahwa keserentakan pelaksanaan pemilu merupakan suatu formula alternatif bagi perubahan sistem politik dan pemerintahan. Hal ini didasarkan pada pengalaman dan upaya untuk mengatasi berbagai problematika yang ada, yaitu: menjadi dasarbagi terealisasinya sistem pemerintahan presidensialisme yang kuat dan stabil; memfasilitasi munculnya penyederhanaan sistem kepartaian, melalui pemberian insentif bagi partai politik untuk membangun budaya dan pelembagaan politik demokratis yang berkelanjutan (Aliansi, Koalisi, Gabungan, dan atau Merger); mendorong pembentukan parlemen yang lebih efektif; Menciptakan sistem pemilihan yang lebih sederhana, waktu yang singkat, sekaligus biayamurah baik dalam pemilu legislatif maupun pemilihan umum presiden; Menciptakan ruangbagi munculnya fokus isu dalam pemilu, mana yang merupakan isu nasional dan mana isu lokal; Membuka ruang partisipasi bagi menguatnya preferensi dan strategi rakyat (pemilih) padapemilu berdasarkan isu lokal maupun nasional; Agar tujuan-tujuan di atas dapat terealisir secara efektif, maka sistem pemilu presiden runnof with a reduced threshold (mayoritas bersyarat)Jurnal Ilmiah Ilmu Pemerintahan 3(1), 2018. merupakan pilihan utama. Adapun persyaratan yang diterapkan adalah; pasangan PresidenWakil Presiden terpilih pada putaran pertama, jika meraih $45 \%$ suara dengan jarak 5 persendari kandidat kedua, atau $40 \%$ suara dengan jarak $10 \%$ suara dari kandidat kedua (Wijayanti \& Purwaningsih, 2015: 51).

Desain pemilu serentak di kebanyakan negara lain seperti dikemukakan oleh Jones dan banyak peneliti lain di Amerika Latin (Wijayanti \& Purwaningsih, 2015: 52) menyatakan bahwa sistem pemilu legislatif dan eksekutif dalam sistem presidensial multipartai haruslah mengkombinasikan waktu pelaksanaan yang serentak, sistem Proporsional dalam pemilu legislatif, dan sistem plurality dalam menentukan pemenang pemilu presidennya. Sistem plurality sendiri sebetulnya cenderungmenghasilkan sedikit kandidat presiden. Ketika pemilu presiden para pendukung kandidat dalam sistem ini cenderung mengabaikan Para kandidat yang tidak kompetitif (nonaviable) supaya mereka dapat fokus pada dua kandidat teratas. Hal ini mendorong proses koalisi antar partai Sejak awal karena hanya ada satu putaran pemilihan. Partai yang mestinya mengajukan calon sendiri namun calonnya kurang kompetitif cenderung akan mendrop calonnya dan 


\section{CIVICS EDUCATION AND SOCIAL SCIENSE JOURNAL(CESSJ)}

meng-endorse satu di antara dua calon paling kompetitif dengan harapan akan mendapatkan konsesi politik pasca pemilu presiden.

Dampak - reduktif dari sistem plurality menjadi tidak berpengaruh terhadap penyederhanaan partai di legislatif, dengan asumsi pemilu legislatif dilaksanakan dengan sistem proporsional. Mekanisme plurality ini berpengaruh terhadap partai-partai ketika dilaksanakan serentak dengan pemilu legislatif. Partai-partai cenderung akan mencalonkan salah satu dari dua kandidat paling kompetitif, dan berujung pada mengumpulnya dukungan partai-partai legislatif pada dua kandidat tersebut. Ketika salah satu dari kandidat itu memenangkan pemilu presiden, maka dukungan terhadap presiden tersebut di legislatif cenderung akan mayoritas atau mendekati mayoritas.

Dengan demikian gabungan sistem pemilu presiden plurality yang dilaksanakan serentak dengan pemilu legislatif adalah yang paling mungkin membantu penguatan sistem presidensial multipartai. Sistem pemilu presiden dengan majority runoff, di sisi lain, cenderung memiliki dampak inflationary terhadap jumlah partai, sekalipun dilaksanakan serentak dengan pemilu legislatif.

Partai dan kandidat yang berkompetisi dalam sistem ini lebih terfokus pada bagaimana maju ke putaran kedua. Selama tidak ada kandidat yang sangat dominan maka seorang kandidat yang memperoleh minimal sepertiga dari suara punya kemungkinan untuk maju ke putaran kedua (Wijayanti \& Purwaningsih, 2015: 52)
Metode

Jenis penelitian ini adalah penelitian deskiptif kualitatif. subyek penelitian ini adalah penelitian terhadap Warga Kelurahan Sumber Kecamatan Banjarsari Kota Surakarta yang terdaftar sebagai pemilih pemula yang berjumlah 60 orang, dan objeknya adalah : partisipasi politik, pemilih pemula dan pemili 2019.

Metode Pengumpulan Data yang digunakan adalah sebagi berikut : observasi, wawancara, angket dan dokumentasi. Dalam penelitian ini digunakan Teknik Analisis Data kualitatif yang terdiri dari 4 tahap yaitu: pengumpulan data, reduksi data, display data dan verifikasi data.

Hasil Penelitian Dan Pembahasan

1. Hasil Penelitian

Hasil pengamatan dilapangan terhadap sikap, perilaku, dan perbuatan pemula dalam partisipasi politik pada PEMILU tahun 2019 ditemukan hal-hal sebagai berikut: pendirian pemilih pemula sering berubah-ubah dalam hal mengenakan atribut kampanye, umumnya pemilih pemula tidak kenal calon yang akan dipilihnya, pemilih pemula lebih suka memilih calon muda, pemilih pemula lebih suka caleg yang suka member atribut atau apa saja yang mnjadi ksukaan pemilih pemula, pemilih pemula tidak suka caleg yang banyak janji.

Hasil wawancara dengan para pemilih pemula diperolh informasi: caleg yang agamis menjadi sasaran untuk dipilihnya, pemilih pmula tidak suka caleg yang berusia tua, pemilih 


\section{CIVICS EDUCATION AND SOCIAL SCIENSE JOURNAL(CESSJ)}

pmula lebih suka caleg muda yang energy, pemilih pemula lebih menyukai caleg yang memiliki program program yang realistis, pemilih pemula tidak suka caleg yang mengobral janji, pemilih pemukla banyak yang ikut kampanye lebih dari satu partai politik karena baginya kampanye menjadi suatu hiburan yang mengasikan, para pemilih pemula mau jadi tim kampanye jika ada logistiknya.

Hasil wawancara dengan panitia di TPS diperoleh informasi banyak pemilih pemula yang bersikap kurang proaktif dengan panitia TPS, banyak pemilih pemula yang membisikki pada pemilih tua supaya mencoblos caleg tertentu, ada juga pemilih pemula yang mengajak untuk tidak menggunakan hak pilihnya.

Sedangkan Mengacu pada materi koisioner yang terdiri atas 4 indikator yang kemudian dijabarkan menjadi 20 pertanyaan kuisioner untuk responden maka dalam Partisipasi Politik Pemilih Pemula Dalam Pemilihan Umum 2019 Di Kelurahan Sumber dapat dijelaskan sebagai berikut :

Peningkatan partisipasi politik pemilih pemula yang berkaitan dengan kesadaran berpartisipasi politik. Sebanyak 60 responden yang diberikan kuisioner untuk mengisi dan setelah itu dilakukan perhitungan sebanyak $87,9 \%$ memilih sangat setuju. Hal ini berarti pemilih pemula di lingkungan Kelurahan Sumber sudah banyak yang memahami akan pentingnya kesadaran dalam berpartisipasi politik.

$\begin{array}{rrr}\text { Partisipasi } & \text { politik pemilih } \\ \text { pemula yang berkaitan } & \text { dengan }\end{array}$ golongan putih ( golput ) merupakan tindakan yang baik, sebanyak 60 responden diberikan kuisioner untuk mengisi dan setelah itu dilakukan perhitungan dengan hasil sebanyak $88,3 \%$ menjawab sangat tidak setuju. Hal ini dapat disimpulkan bahwa pemilih pemula sadar jika golongan putih ( golput ) tindakan yang kurang baik karena golput dapat memengaruhi hasil perhitungan suara. Golongan putih bukan suatu tindak pidana tetapi jika ada orang yang memobilisasi untuk melakukan golongan putih dapat dipidanakan seperti yang diatur dalam UU No.7 Tahun 2017 tentang pemilihan Umum pasal 515 dijelaskan "setiap orang yang dengan cara apapun menghalangi pemilih , penjara paling lama tiga tahun dan denda 36 juta".

Peningkatan partisipasi politik pemilih pemula yang berkaitan dengan situasi politik mempengaruhi dalam partisipasi politik, sebanyak 60 responden yang mengisi kuisioner dan setelah dilakukan perhitungan sebanyak 74,5\% menjawab setuju. Hal ini dapat disimpulkan bahwa pemilih pemula melihat situasi dan kondisi politik menjelang pemilihan sebelum menentukan pilihannya, sikap seperti ini yang harus dilakukan pemilih pemula agar dalam menentukan pilihannya tidak salah pilih.

Peningkatan partisipasi politik pemilih pemula yang berkaitan dengan menggunakan hak suara karena suruhan orang lain, sebanyak 60 responden yang diberikan kuisioner untuk mengisi dan setelah dilakukan perhitungan sebanyak $87 \%$ menjawab sangat tidak setuju . hal ini dapat disimpulkan bahwa dalam menggunakan hak suara tidak ada pemaksaan atau suruhan dari orang lain karena dalam pemilihan umum 


\section{CIVICS EDUCATION AND SOCIAL SCIENSE JOURNAL(CESSJ)}

mempunyai asas langsung, umum, bebas, rahasia, jujur, dan adil.

Partisipasi politik pemilih pemula yang berkaitan dengan menggunakan hak suara dalam pemilihan umum memiliki rasa kesadaran sebagai warga negara, sebanyak 60 responden yang diberikan kuisioner untuk mengisi dan setelah itu dilakukan perhitungan sebanyak 84,1 $\%$ menjawab sangat setuju . hal ini dapat disimpulkan bahwa pemilih pemula sadar sebagai warga negara yang baik harus menggunakan hak suaranya untuk masa depan bangsa Indonesia.

Partisipasi politik pemilih pemula yang berkaitan dengan suap dalam pemilihan umum tindakan yang kurang baik, sebanyak 60 responden yang diberikan kuisioner untuk mengisi dan setelah itu dilakukan perhitungan sebanyak 76,2 \% menjawab sangat setuju. Hal ini dapat disimpulkan bahwasebagian besar pemilih pemula tidak mau menerima money politic karena pemilih pemula mengetahui kalau money politic dapat merusak moral bangsa dan bagian dari Kolusi, Korupsi, dan Nepotisme. Suap atau money politic ini dapat dipidanakan sesuai UU No.7 Tahun 2017 tentang Pemilihan Umum pasal 515 yang berbunyi "setiap orang dengan senagaja pada saat pemungutan suara menjanjikan atau memberikan uang atau materi lainnya kepada pemilih supaya tidak menggunakan hak pilihnya dengan cara tertentu sehingga surat suaranya tidak sah, dipidanakan penjara paling lama 3 tahun dan denda paling banyak 36 juta".

Partisipasi politik pemilih pemula yang berkaitan dengan pemilih pemula kecewa jika yang dipilih sesuai harapan, sebanyak 60 responden yang diberikan kuisisoner untuk mengisi dan setelah dilakukan perhitungan sebanyak 62,9 \% menjawab setuju. Hal ini dapat disimpulkan bahwa pemilih pemula aktif dalam bidang politik terutama mengawasi kinerja calon presiden dan calon wakil presiden maupun calon legislatif yang visi dan misi saat kampanye tidak terealisasi hanya janji manis saat kampanye.

\section{Pembahasan}

Kesadran politik warga negara menjadi faktor determinan dalam partisipasi politik masyarakat, artinya sebagai hal yang berhubungan pengetahuan dan kesadaran akan hak dan kewajiban yang berkaitan dengan lingkungan masyarakat dan kegiatan politik menjadi ukuran dan kadar seseorang terlibat dalam proses politik. Alasan seseorang melakukan aktifitas politik yaitu : pertama, alasan rasional, yaitu alasan yang didasarkan atas penerimaan secara rasional akan nilainilai suatu kelompok. Kedua, alasan emosional efektif adalah alasan yang didasarkan pada kebencian atau suka terhadap suatu ide, organisasi, partai atau individu. Ketiga, alasan tradisional, yaitu alasan yang didasarkan atas penerimaan norma tingkah laku individu atau tradisi tertentu dari kelompok sosial. Keempat, alasan rasional instrumental, yaitu alasan yang didasarkan pada kalkulasi untung rugi secara ekonomi.

Bagi pemilih pemula di

Kelurahan Sumber ikut serta dalam pemilku serentak 2019 ini tentu menjadi sangat berarti karena hal ini akan menjadi pengalaman pertama dan menjadi pembelajaran untuk pemilih pemula di Kelurahan Sumber, ketika akan diadakan pemilihan umum serentak 2019 dalam menghadapi proses demokrasi ini tentunya pemilih 


\section{CIVICS EDUCATION AND SOCIAL SCIENSE JOURNAL(CESSJ)}

pemula mempunyai peranan sangat penting dan sangat menentukan. Agar dapat berperan aktif dalam berpartisipsi tentunya pemilih pemula harus tahu mengenai pelaksanaan pemilu serentak 2019 untuk memilih calon presiden wakil presiden serta anggota legislatif.

Dari hasil penelitian yang dilaksanakan untuk mengetahui tinggi rendahnya partisipasi politik pemilih pemula di Kelurahan Sumber didapatkan bahwa pemilih pemula di Kelurahan Sumber mempunyai kesadaran politik dalam keikutsertaanya dalam pemilu 2019 untuk memilih calon presiden dan wakil presiden serta calon anggota legislatif.

Kesadaran pemilih pemula ini karena pemilih pemula mengetahui kesadaran sebagai warga negara yang baik, mempunyai hak dan kewajiban sebagai warga negara. Kesadaran politik juga diperoleh dari sekolah melalui pelajaran Pendidikan Pancasila dan Kewarganegaraan serta peran orang tua yang memberikan pengetahuan tentang kesadaran politik dalam keikutsertaan dalam pemilu, selain itu kesadaran politik pemilih pemula untuk menilai dan mengapresiasi terhadap kbijak pemerintah dan pelaksanaanya

Pemilih pemula di Kelurahan Sumber dalam pemilu 2019 memberikan pendapat jika golput merupakan tindakan yang kurang baik, golput adalah salah satu bentuk perlawanan terhadap praktik politik dari orang-orang yang kecewa terhadap penyelenggaraan negara dengan cara tidak memilih dalam pemilu. Tindakan golput ini dapat mempengaruhi hasil perhitungan suara, golput juga bukan tindakan pidana tetapi jika ada orang yang mempengaruhi untuk tidak memberikan hak suaranya dapat dipidanakan peraturan tersebut terdapat dalam UU No.7 Tahun 2017 tentang pemilihan umum pasal 515 dijelaskan "setiap orang yang dengan cara apapun menghalangi pemilih, penjara paling lama tiga tahun dan denda 36 juta rupiah".

Situasi politik juga dapat mempengaruhi dalam berpartisipasi politik, hal ini dapat dirasakan menjelang pemilihan umum situasi banyak berita yang memuat kebohongan, saling mengujar kebencian, isu SARA. Bagi pemilih pemula di Kelurahan Sumber situasi politik ini sangat diperhatikan untuk menggunakan hak suaranya dalam pemilu 2019 agar dalam menggunakan hak pilihnya tidak salah pilih.

Pemilih pemula kecewa jikayang dipilih tidak sesuai harapan juga dapat mempengaruhi tinggi rendahnya partisipasi politik, karena jika calon yang dipilih tersebut terpilih lalu tidak melaksanakan program yang sudah dijanjikan pada waktu kampanye dapat mempengarhui tinggi rendahnya partisisipasi politik kedepan jika akan diadakan pemilihan umum. Bagi pemilih pemula di Kelurahan Sumber sebagian besar merasa kecewa jika yang diharapkan tidak sesuai harapan yang diinginkan seperti pada waktu kampanye, hal ini dapat disimpulkan bahwa pemilih pemula di Kelurahan Sumber aktif dalam mengawasi jalannya pemerintahan untuk kemajuan bangsa Indonesia, meskipun pemilih pemula merasa kecewa tidak sesuai harapan pemilih pemula di Kelurahan Sumber tetap aktif dalam berpartisipasi politik khususnya dalam pemilu yang akan datang. 


\section{CIVICS EDUCATION AND SOCIAL SCIENSE JOURNAL(CESSJ)}

Volume 1, Nomor 1, Juni 2019

\section{Simpulan}

Dari hasil penelitian yang penulis lakukan melalui judul sebagaimana tersebut di atas maka penulis menarik kesimpulan yaitu berupa :
Terjadi Peningkatan Partisipasi Politik yang segnifikan pada pemilih pemula di Kelurahan Sumber dan pemilih pemula di Kelurahan Sumber sangat antusias dan bersemangat untuk mengikuti partisipasi pemilih

\section{Daftar Pustaka}

A. Rahman, H.I.2017. Sistem Politik Indonesia. Yogyakarta: Graha Ilmu Arstein, S.R 1995, A Ladder Of Citizen Participation, JAIP. Vol. 35, No.4, July 1969, PP.216-224

Cholisin, dkk.2007. Dasar-dasar /!mu Politik: Yogyakarta: UNY Press Miriam Budiardjo.2008. Dasar-dasar Jlmu Politik: Jakarta: PT Gramedia Pustaka

Moleong, Lexy.2010. Metode Penelitian Kualitatif. Bandung: PT. Remaja Rosdakarya

Ramlan Subakti.1992. Memahami I/mu Politik. Jakarta: PT Grasindo

Rizal Andreeyan.2004. Studi Tentang Partisipasi Masyarakat Dalarn Melaksanakan Pembangunan Di Kelurahan Sambutan Kecamatan Sambutan Kota Samarinda. (Online), Vol.2, No.4, (http://secafirmansyah.wordpress.com/2009/06/05/partisipasimasyoraka0

Sugiyah 2010. Partisipasi Komite Sekolah daJam Penyclenggaraan K rnusan Sekolah Bertaraf Intemasional di Sekolah Dasar Ncgcri IV Wates, Kabupaten Kulon Progo Tests. PPs UNY.

Sumampouw, Monaque2004. Perencanaan Darat-laut Yang Tenntegrost dcngan Menggunalcan Informast Spasial yang Parll ipauf. Jakarta Prndrvn Paramita

Winamo Surahmad J 973. Pengantar Penelutan llmsah: Bandung

https://scholar.google.co.id/scholar?g=kajian+teori+tentang+peningkatan+parti sip asi+politik\&hl=en\&as $\quad \mathrm{sdt}=\mathrm{O} \&$ as $\quad$ vis=l\&oi=scholar https://sej arahlengkap.com/indonesia/sejarah-pemilu-di-indonesia

http://www.jdih.set!en.kemendagri.go.id/pm/UU\%20No.

7\%20TH\%202017.pdf 